\title{
Wnt Signaling in Thyroid Homeostasis and Carcinogenesis
}

\author{
Kim A. Ely ${ }^{1}$, Lindsay A. Bischoff ${ }^{2}$ and Vivian L. Weiss ${ }^{1, *}$ (ib \\ 1 Department of Pathology, Microbiology, and Immunology, Vanderbilt University Medical Center, Nashville, \\ TN 37232, USA; kim.ely@vanderbilt.edu \\ 2 Department of Medicine, Vanderbilt University Medical Center, Nashville, TN 37232, USA; \\ lindsay.bischoff@vanderbilt.edu \\ * Correspondence: vivian.l.weiss@vanderbilt.edu; Tel.: +615-875-3002
}

Received: 26 December 2017; Accepted: 9 March 2018; Published: 10 April 2018

\begin{abstract}
The Wnt pathway is essential for stem cell maintenance, but little is known about its role in thyroid hormone signaling and thyroid stem cell survival and maintenance. In addition, the role of Wnt signaling in thyroid cancer progenitor cells is also unclear. Here, we present emerging evidence for the role of Wnt signaling in somatic thyroid stem cell and thyroid cancer stem cell function. An improved understanding of the role of Wnt signaling in thyroid physiology and carcinogenesis is essential for improving both thyroid disease diagnostics and therapeutics.
\end{abstract}

Keywords: thyroid cancer; Wnt signaling; cancer stem cells

\section{Introduction}

Somatic (adult) stem cells are necessary for homeostasis across a variety of tissues. Among the best-characterized examples are the gastrointestinal tract, where there is rapid turnover of the epithelium [1,2], and hematopoietic tissues, which have a strong capacity to regenerate that is dependent on the presence of long-term somatic stem cells [3]. In both cases, Wnt signaling is needed for stem cell survival and for the upkeep of their tissue regenerative capacity [1,4]. While normal thyroid tissue has a low turnover rate, during times of injury, it has an immense capability for cellular renewal. Given the critical nature of Wnt signaling in the maintenance of stem cells in other tissues [5,6], it is not surprising that Wnt signaling has been implicated in thyroid development, homeostasis, and carcinogenesis $[7,8]$.

Thyroid disease affects 20 million Americans, with approximately one in 20-30 people in the United States diagnosed with hypothyroidism, or insufficient thyroid hormone [9]. Artificial thyroid hormone replacement with levothyroxine is the standard of care for hypothyroidism. However, despite this treatment, individuals with such thyroid dysfunction suffer from imbalances in cell metabolism, which can affect many important tissues throughout the body, including skin, bones, brain, and intestine. Thus, the management of exogenous thyroid hormone is of critical importance and remains a challenge.

Thyroid hormone (TH) plays a role in many cellular functions, including proliferation, growth, differentiation, metabolism, regeneration, and homeostasis. It is produced by the thyroid gland and then travels through the bloodstream to regulate gene transcription at diverse sites. While the hypothalamic/pituitary/thyroid axis controls thyroid hormone synthesis, TH is so critical for cellular function that it is also tightly regulated at the level of the individual tissues. Thyroid hormone enters cells by membrane transport and is modified by deiodinases on its path from the membrane to the nucleus. By catalyzing the release of iodine from thyroid hormones, deiodinases allow for tissue-specific regulation of cellular levels of active thyroid hormone. Each tissue tightly controls the 
expression of various deiodinase isoforms to allow for precise regulation of active thyroid hormone concentrations. Once thyroid hormone reaches the nucleus, it binds to its nuclear receptors, which regulate gene transcription. Thyroid hormone receptors (TRs) provide another level of cellular control of TH actions. Recent evidence suggests that Wnt/ $\beta$-catenin signaling (henceforth simply "Wnt signaling") is involved in regulating the expression of TRs and deiodinases in the target tissues to allow for TH-driven transcriptional programs.

While somatic stem cells have been well-characterized in a variety of tissues, their function in thyroid regeneration and thyroid cancer is just beginning to be described. In addition, our understanding of the role of Wnt signaling in both normal and neoplastic thyroid epithelial proliferation is evolving. Herein, we review the development and physiology of the thyroid gland and the emerging evidence for the role of Wnt signaling in thyroid development, maintenance of adult thyroid stem cells, and thyroid cancer. Finally, we discuss the future directions for defining the role of the Wnt pathway in thyroid stem cell research and the important questions that remain to be answered.

\section{Thyroid Physiology and the Molecular Mechanisms of Thyroid Hormone Function}

The thyroid gland is essential for organism homeostasis due to its role in the production of TH. TH is controlled by the hypothalamic/pituitary/thyroid axis, leading to downstream stimulation of its production and regulation by a feedback mechanism. However, TH is also tightly monitored at the level of the individual tissues. There is evidence that Wnt signaling plays a role in thyroid hormone function and regulation.

\subsection{Thyroid Hormone Regulation and Signaling}

TH has long been known to regulate metabolism. Patients with TH dysfunction often display the symptoms of metabolic dysregulation, including fatigue and weight changes. TH synthesis is controlled by the hypothalamic/pituitary/thyroid axis. Thyrotropin-releasing hormone (TRH) is synthesized in the hypothalamus and migrates to the anterior pituitary through the portal capillary plexus [10]. TRH receptors are present within the membranes of anterior pituitary cells, and their stimulation leads to release of thyroid-stimulating hormone (TSH). TSH is responsible for regulating TH secretion by the thyroid gland. It binds to the membrane receptor (TSHR) in the thyroid gland and stimulates production of $\mathrm{TH}$, the $\mathrm{Na}^{+} / \mathrm{I}^{-}$symporter (NIS), thyroglobulin (Tg), and thyroid peroxidase (TPO). NIS transports iodide into the cell, which is oxidized by TPO and incorporated into $\mathrm{Tg}$. Monoiodinated and diiodinated $\mathrm{Tg}$ residues are enzymatically coupled to form thyroxine (T4) and triiodothyronine (T3) [10]. T4 and T3 are then emitted into the blood stream. T4 is the major form and is 40-fold higher in the serum than the active form, T3. T4 is catalyzed to its active form, $\mathrm{T} 3$, in peripheral cells. Most TH travels through the circulation bound to thyroxine-binding globulin (TBG), albumin, or thyroid-binding prealbumin [10]. Once TH enters the cell, T3 binds to nuclear thyroid hormone receptors, which heterodimerize and bind to thyroid hormone response elements (TREs) in the promoter regions of genes, thereby enhancing transcription of target genes [11].

While plasma concentrations of TH are relatively stable, tissues can coordinate different $\mathrm{TH}$ levels due to their regulation of deiodinases and thyroid hormone receptors. The iodothyronine deiodinase family of selenoproteins are enzymes that include D1, D2, and D3. These deiodinases are present in specific tissues in order to regulate thyroid hormone activation and inactivation. The differential expression of deiodinases allows for tight control of $\mathrm{T} 3$ and its prohormone, $\mathrm{T} 4$ [12]. T4 has a longer half-life and is converted to the active form, T3, within cells through deiodinases. D1 is the most abundant deiodinase and is found predominantly in liver and kidney, and to a lesser extent in skeletal muscle, heart, and thyroid tissue (Table 1). Because its major goal is to release active thyroid hormone, T3, into the circulation, it converts T4 from the thyroid into T3 by deiodination of the T4 outer ring [13]. In hyperthyroidism, D1 function is increased, resulting in supraphysiologic T3 levels in the circulation. $\mathrm{D} 2$ is responsible for the intracellular conversion of $\mathrm{T} 4$ to the active form $\mathrm{T} 3$, by $5^{\prime}$-deoiodination or removal of iodine. D2 is negatively regulated by thyroid hormone in order to increase T4 to T3 
conversion within the target tissues during times of low thyroid hormone [12,14]. D2 is predominantly expressed in the central nervous system (CNS) to regulate active thyroid hormone levels in the brain (Table 1). D3 is responsible for inactivation of thyroid hormones to maintain homeostasis. D3 deiodinates the inner ring of the T4 molecule, resulting in 3,3', $5^{\prime}$-triiodothyronine, or reverse T3. D3 also deiodinates T3 to 3,3'-diiodothyronine, or T2. D3, predominantly expressed in the placenta and brain, is elevated in hyperthyroidism, thereby serving a protective function from fetal hyperthyroidism and maintaining CNS euthyroidism (Table 1). Similarly, D3 function is decreased in hypothyroidism to maintain active homeostasis.

Table 1. Deiodinase expression in human tissue and its role in normal tissue function as well as in hyper- and hypothyroid states.

\begin{tabular}{ccccc}
\hline Tissue & Deiodinase Expression & Normal Function & Hyperthyroidism & Hypothyroidism \\
\hline $\begin{array}{c}\text { Thyroid Liver Kidney } \\
\text { Skeletal muscle }\end{array}$ & D1 & Production of T3 into plasma & Increased function & Decreased function \\
\hline Brain & D2 & $\begin{array}{c}\text { Production of T3 into } \\
\text { plasma and local tissues }\end{array}$ & Decreased function & Increased function \\
\hline Placenta Brain & D3 & Degradation of T3 & Increased function & Decreased Function \\
\hline & & T3: thyroxine. & &
\end{tabular}

TH action can also be controlled at the cellular level by the expression of various thyroid hormone receptors. TR mRNA can be variably spliced to form $\operatorname{TR} \alpha(\mathrm{TR} \alpha 1$, TR $\alpha 2$, and $\mathrm{TR} \alpha 3$ ) and TR $\beta$ (TR $\beta 1$ and TR $\beta 2$ ) [15]. These receptors can heterodimerize and bind to regulatory regions of DNA with the retinoid $X$ receptor (RXR) (Figure 1) [11]. They can also form less transcriptionally active units as homodimers or monomers when they bind DNA [15]. Tissue-specific expression of the various isoforms helps to regulate the level of $\mathrm{TH}$ signaling as well as the proliferative or differentiating function of TH action.

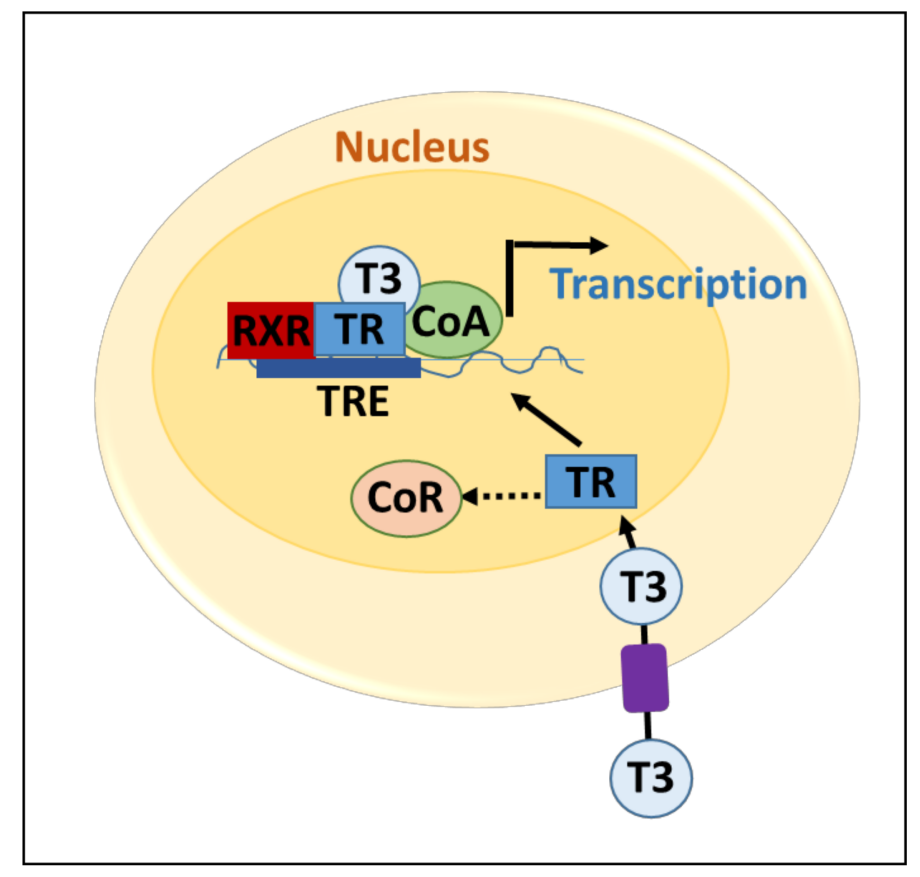

Figure 1. Thyroid hormone receptor-mediated transcription. T3 enters the target cell through membrane transport. T3 enters the nucleus and binds to the thyroid hormone receptor (TR). TR then releases the co-repressor (CoR), dimerizes with the retinoid $X$ receptor (RXR), and recruits the co-activator (CoA) complex. This complex binds the $\mathrm{T} 3$ response element (TRE) to activate transcription of target genes. 
Recently, dynamic regulation of TH at the tissue level has been demonstrated to be critical not only in normal development, but also in aberrant neoplastic tissue growth. In a variety of cancer types, cancer stem cells (cells within a cancer that have the ability to self-renew and drive tumorigenesis) have been proposed to modulate thyroid hormone's effects through deiodinase and TR expression [16-19]. This interplay is thought to rely, in part, on Wnt signaling within cancer stem cells. Here, we review the effect of TH on cancer stem cell regulation and the current evidence for the role of Wnt pathway signaling in mediating tissue-specific, dynamic TH control.

\subsection{Regulation of the Wnt Pathway by Thyroid Hormone Receptors}

The actions of TH and Wnt signaling have been shown to reciprocally influence each other. In the current model of Wnt signaling, if Wnt ligand is absent, $\beta$-catenin is degraded through its association with a destruction complex that includes glycogen synthase kinase 3 (GSK3), casein kinase 1(CK1), adenomatous polyposis coli (APC), and Axin [20]. Wnt pathway activation is initiated upon binding of Wnt ligands to members of the Frizzled (FZD) and LRP5/6 co-receptor family. This process ultimately leads to receptor activation via a mechanism involving the cytoplasmic protein, Dishevelled (Dvl). As a consequence, $\beta$-catenin is stabilized and translocated to the nucleus, where it mediates a Wnt-specific transcriptional program. The current evidence indicates that the interaction between Wnt signaling and TH signaling is likely context-dependent, and they act to either antagonize or potentiate each other's functions in order to maintain homeostasis within different target tissues [17,21-24].

TH has been demonstrated to act on the Wnt pathway in tissues both during development and in neoplasia. In a rat pituitary model that is often used to study thyroid hormone and its receptors, activated TH, T3, induces cellular proliferation in pituitary cells and Wnt pathway silencing [24]. Specifically, following T3 stimulation, there is a decrease in levels of $\beta$-catenin and an increase in levels of Axin. Axin is part of the destruction complex responsible for ubiquitination of $\beta$-catenin. The group also demonstrates, using a luciferase reporter, that T3 treatment results not only in decreased $\beta$-catenin, but also in decreased transcriptional activity of the $\beta$-catenin-T-cell Factor (TCF) complex. It was proposed that translational and posttranslational mechanisms may regulate this Wnt silencing. This finding is opposite to the effect of T3 on colon cancer cells, where T3 exposure reduced tumor proliferation [18]. The contrasting effect of $\mathrm{T} 3$ on the behavior in colon cancer cells versus other tissues is speculated to be due to differences in the expression of deiodinases and TRs that may modify the oncogenic effects of Wnt signaling [18,23].

Distinct mechanisms by which thyroid hormone receptors regulate Wnt signaling have been described. TRs can affect transcription at the level of Wnt target gene promoters. TRs heterodimerize and bind to TREs located in regulatory regions of target genes. In the T3-free state, TRs interact with transcriptional co-repressors to inhibit target genes. When T3 binds, however, co-repressors are displaced and co-activators are recruited [25]. Thus, transcription of TR target genes is monitored by a differential co-repressor-co-activator recruitment pathway. Natsume et al. have shown that in colon cancer, T3 binding to TR $\beta 1$ can suppress Wnt signaling by inhibiting $\beta$-catenin/TCF/LEF-1-mediated transcription of cyclin D1 (Figure 2) [26]. In addition to regulating the promoters of Wnt target genes, TRs can also bind directly to $\beta$-catenin. Guigon et al. used a mouse model of thyroid cancer to evaluate the interactions of TR $\beta$ and $\beta$-catenin [17]. They found that TR $\beta$ binds to $\beta$-catenin and that T3 binding disrupts this interaction, which enhances $\beta$-catenin proteasomal degradation and decreases Wnt signaling. Furthermore, using a TR $\beta^{P V / P V}$ mouse model in which the TR $\beta$ mutant is unable to bind T3, they demonstrated that $\beta$-catenin levels are elevated [17]. In summary, differential expression of TRs in tissues can lead to changes in Wnt/ $\beta$-catenin signaling within target tissues via distinct mechanisms. 


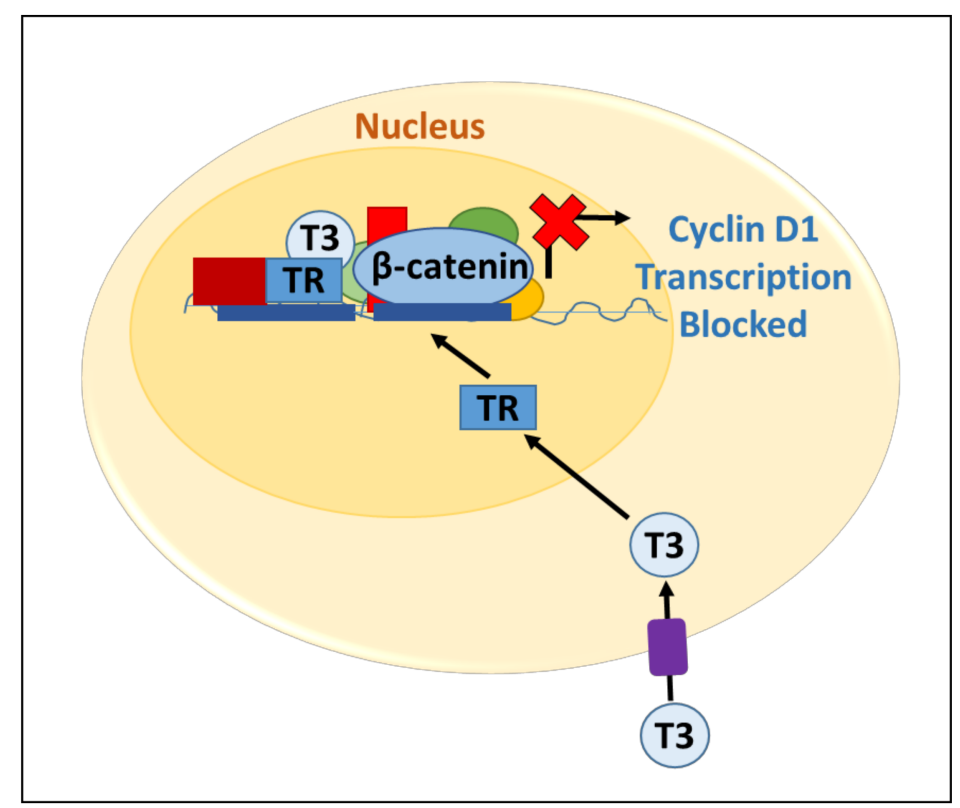

Figure 2. The effects of T3 on cyclin D1 transcription in colon cancer. T3 enters the target cell through membrane transport. T3 enters the nucleus and binds to the thyroid hormone receptor (TR). TR then recruits the co-activator complex. This complex then inhibits transactivation by $\beta$-catenin/TCF on the Cyclin D1 promoter.

\subsection{Control of Thyroid Hormone Function by the Wnt Pathway}

The Wnt pathway has been shown to indirectly regulate TH function. Deiodinases are tightly controlled target genes of the Wnt pathway. Specifically, the management of D3 and D2 transcription is dynamically regulated by multiple signaling pathways, including the Wnt pathway [23]. The differential regulation of D2 and D3 is important during fetal development in protecting certain organs from T3 over-exposure; specifically, target organs can increase D3 expression to inactivate thyroid hormone and decrease D2 expression to prevent additional activation of thyroid hormone. One such T3-sensitive organ is the retina. During development of cones and color vision, D3 must be highly expressed in order to protect these cells from excessive T3 [21,22]. Elevated D3 also influences the development of the hypothalamic-pituitary-thyroid axis, as D3 knock-out mice have central hypothyroidism [27]. Studies of D3 knock-out in zebrafish have also revealed the significant contribution of D3 regulation to normal development [28].

The control of deiodinases by Wnt signaling is best described using a colon cancer model, where D3 expression is increased and D2 expression is decreased following Wnt stimulation [18]. D3 promoters are thought to be direct targets of Wnt signaling, where the $\beta$-catenin-TCF- 4 complex binds to and regulates these promoters. D2 is also thought to be a direct target of Wnt signaling, but the molecular mechanisms of this regulation have yet to be elucidated. Indeed, transfection of a dominant-negative TCF- 4 into a colorectal carcinoma cell line with constitutively active $\beta$-catenin led to increased D2 mRNA and decreased D3 mRNA [18]. Chromatin immunoprecipitation experiments have demonstrated that $\beta$-catenin associates with the promoter region of the D3 gene to mediate its transcription [18].

Control of D3 expression by Wnt signaling in intestinal stem cells blocks differentiation and plays a role in colonic tumorigenesis. Intestinal stem cells are required to provide regeneration and maintenance of this epithelium [1,29]. This homeostatic process is regulated by the Wnt- $\beta$-catenin pathway, and over-activation of this pathway is a main driver of colon cancer [30]. Within the intestinal epithelium, $\beta$-catenin expression leads to D3 upregulation and D2 downregulation [18]. In the colonic epithelium, this control of D2 and D3 expression by the Wnt pathway has been shown to participate in 
colon cancer neogenesis (Figure 3) [18]. Specifically, induction of D3 by the Wnt pathway monitors the production of active TH to prevent differentiation of the neoplastic intestinal cells. Consistent with this, the addition of T3 to colon cancer cells reduces the proliferative capacity of the tumor [18] via its effects on differentiation.

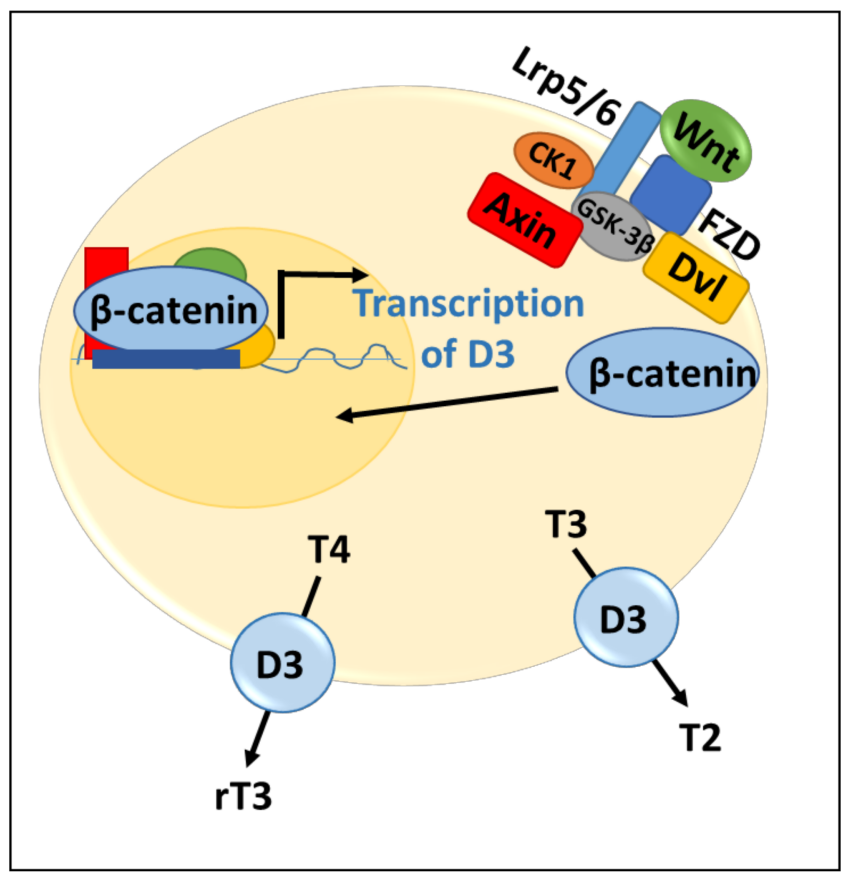

Figure 3. Wnt signaling pathway regulates deiodinases. Wnt ligand binds to the receptor, Frizzled (FZD), and the co-receptor, lipoprotein receptor-related protein 5 or 6 (Lpr5/6). Disheveled (Dvl) is then recruited, leading to phosphorylation of Lrp5/ 6 by casein kinase 1 (CK1) and glycogen-synthase kinase $3 \beta$ (GSK-3 $\beta$ ). Axin then binds, allowing for $\beta$-catenin to accumulate and translocate to the nucleus to activate transcription of D3. D3 levels then increase and lead to inactivation of T4 to reverse triiodothyronine (rT3) and T3 to T2.

\section{Thyroid Gland Development and Adult Stem Cells}

$\mathrm{TH}$, which is secreted solely by the thyroid gland, is critical for homeostasis within an organism. The development and maintenance of the thyroid gland is essential for the upkeep of tissues throughout the body. Errors during thyroid development lead to congenital defects in the thyroid gland and the inability to form adequate thyroid hormone in children. Autoimmune diseases, iodine deficiency, and thyroid surgery result in insufficient thyroid hormone production in adults. While the presence of thyroid stem cells has recently been demonstrated [31,32], the pathways essential for stem cell function are still poorly understood. The Wnt signaling pathway is responsible for stem cell maintenance in many organs $[5,6]$, and there is mounting evidence that it may also play a role in thyroid homeostasis via regulation of thyroid stem cells [7].

\subsection{Thyroid Gland Development}

The thyroid gland is composed of differentiated thyroid follicular epithelium that is organized in spherical follicles. This epithelium is made up predominantly of thyroid follicular cells responsible for the production of thyroid hormone [33]. These cells form spherical thyroid follicles that store and release thyroid hormone. Parafollicular or $\mathrm{C}$ cells are scattered in between these thyroid follicles and produce calcitonin. While these two cell types form a functional thyroid gland, their developmental origins are distinct. 
Thyroid cells develop from two separate structures, the thyroid anlage and the ultimobrachial bodies. Thyroid follicular cells develop from the midline anlage (or diverticulum), which contains endodermal cells and is located in the embryonic mouth cavity. Cells from this foregut endoderm migrate caudally, bifurcate, and become the thyroid follicular cells. The ultimobrachial bodies are derived from the fourth pharyngeal pouch, which is responsible for C-cell development. The ultimobrachial bodies are transient structures located on either side of the embryonic neck. The fusion of the ultimobrachial bodies and thyroid lobes creates this dynamic organ with two distinct and intermixed populations of cells [34,35]. The thyroid gland also contains stromal fibroblasts, a network of capillaries, macrophages, and mast cells [35].

Interestingly, while TSH stimulation of the thyroid is critical for organ maintenance in the adult, fetal development of the thyroid gland is thought to occur without significant TSH stimulation [35-37]. The mechanisms that drive lobation of the thyroid are poorly understood. Similarly, the role of the interactions between endoderm and surrounding structures during organogenesis are still being discovered $[38,39]$. Functional differentiation of thyroid follicular cells does not begin until the cells have finished migration. The process of thyrocyte differentiation relies on signaling events mediated by bone morphogenetic protein (BMP44) and fibroblast growth factor (FGF2) in Xenopus, murine, and human cells [40]. Thyroid progenitor survival and development has been shown to be dependent on Nkx2.1a, Pax2a, Pax 8, Hhex, Titf1/Nkx2-1 (TTF-1), and Foxe1 (TTF-2) among others [41-45]. While the Wnt pathway is known to be activated in these progenitors based on upregulation of Wnt target mRNA, the role of Wnt signaling in thyroid development has not yet been determined [40].

\subsection{Thyroid Gland Stem Cells}

Dumont et al. originally proposed the existence of thyroid adult stem cells $[46,47]$. To date, the identification of thyroid adult stem cells remains challenging, as these cells are believed to be fairly rare in the thyroid. While thyroid cell turnover is quite low (estimated turnover rate of 5 times during a normal lifespan) [46], under certain conditions there is great capacity for thyroid tissue growth and regeneration, such as after partial thyroidectomy or following immune injury. More recently, Thomas et al. defined a population of cells in solid cell nests of normal thyroid that expresses markers of pluripotent cells, including Oct-4, Gata-4, Pax8, and HNF4 $\alpha$ [31]. Chen et al. elucidated the robust regenerative capacity of the thyroid and the possibility of Oct $-4^{+}$adult thyroid stem cells in a murine autoimmune thyroiditis model of thyroid injury [32]. Finally, studies of side population cells (cells that extrude dyes, such as Hoechst 33342, using ATP binding cassette (ABC) transporter proteins) that express stem cell genes critical for self-renewal and pluripotency have been identified in mouse and human thyroid [48].

Recently, Kurmann et al. demonstrated the generation of mouse thyroid progenitor cells from mouse pluripotent stem cells. They showed that thyroid progenitors developed from embryonic stem cell-derived definitive endodermal cells following incubation with BMP4 and FGF2. More importantly, thyroid progenitor cells were generated from normal and disease-specific (hypothyroid) mouse- and human-induced pluripotent stem cells. This study is unique in its ability to generate T4 production from thyroid organoids, as T4 production had not been achieved in prior models. Injection of these organoids into hypothyroid mice resulted in restoration of T4 production [40]. However, further investigation is needed to decipher the number of stem cells required for thyroid tissue generation, their organization within the thyroid, and their normal function during growth and repair.

\subsection{Wnt Signaling in Thyroid Stem Cells}

There is evidence to suggest a role for Wnt signaling in thyroid homeostasis. Several Wnt pathway proteins are expressed in normal thyroid epithelium, including members of the Wnt gene family (Wnt-2, Wnt-3, Wnt-4, Wnt-5a, and Wnt-10b), the Frizzled gene family (Fz-1, Fz-2, and Fz-6), and the Dvl gene family (Dvl-1, Dvl-2, and Dvl-3) [49]. Using a cell-based luciferase reporter assay, Helmbrecht et al. demonstrated TCF/LEF transcriptional activation in thyroid cells [49]. The importance of Wnt 
signaling in the proliferation of human thyroid cells was also highlighted by Chen et al. In their study, GSK-3 $\beta$ gene silencing in primary human thyrocytes using adenoviral-interference resulted in increased expression of $\beta$-catenin and increased cellular proliferation [50].

Interestingly, Kurmann et al. performed microarray analysis of the mRNA expression profiles of thyroid progenitors and found activation of BMP, Wnt, epidermal growth factor, and FGF signaling pathways. BMP4 and FGF2 were sufficient to generate Nkx2-1 $1^{+}$thyroid progenitor cells with $\mathrm{Tg}$, TSHR, NIS, and TPO expression, and the addition of Wnt3a to the cocktail did not alter the lineage specification [40]. The authors replicated this finding in both murine and Xenopus models and suggested that canonical Wnt signaling may not be necessary for this aspect of thyroid progenitor cell generation. Although Wnt signaling was not required for thyroid progenitor cell specification, their mRNA expression profiles were consistent with Wnt pathway activation; this upregulation implies a critical, but currently undefined, role of Wnt signaling in thyroid stem cell biology. In addition, this process of thyroid progenitor initiation is inefficient and requires GFP labeling and cell sorting. The longevity of these cells following transplantation is also not yet defined. Wnt signaling, while not necessary for thyroid specification, may play an essential function in stem cell survival and self-renewal. This possibility is evidenced by the fact that expression of Lgr5, a Wnt target gene that marks stem cells in a variety of tissues, is observed at both mRNA and protein levels in a normal thyroid gland [1,51].

Additional studies are needed to delineate the role of the Wnt pathway in thyroid progenitor function. Identification of Wnt ligands within the stroma of developing thyroid and adult thyroid could clarify the time points at which Wnt signaling is necessary for stem cell function. It will be important to evaluate which cells are responsible for secreting Wnt ligands as well as which cells are receiving the Wnt signal. Finally, identification of the location and organization of stem cells within the adult thyroid has been challenging. As Lgr5 is a common stem cell marker in many tissues and a Wnt target gene, Lgr5 labeling could be useful in identifying stem cell niches within the adult thyroid gland.

\section{Thyroid Cancer and the Role of Wnt Signaling}

Approximately 100 million people in the United States have thyroid nodules, the majority of which are benign and $5-15 \%$ of which are malignant. Thyroid cancer is rapidly increasing in the United States with papillary thyroid carcinoma (PTC) as the most common subtype. While most patients are cured of their PTC following initial therapy, $15 \%$ have disease recurrence, and $\sim 10 \%$ have distant metastatic disease. Current diagnostic testing fails to predict a patient's risk for metastatic or aggressive disease. Correct identification of patients who are at higher risk for recurrence and/or metastasis remains challenging and is an important goal for the field, as it would allow for a more appropriate selection of patients for surgical and radio-iodine therapy. An understanding of thyroid cancer stem cell biology would pave the way for tremendous advances in thyroid cancer diagnostics, prediction of metastatic and recurrent disease, and improved treatment algorithms to prevent unnecessary surgeries. Emerging data show that cells with stem-cell-like properties are present within numerous thyroid cancer cell lines and that Wnt signaling affects their function.

\subsection{Evidence for Wnt Signaling in Thyroid Cancer Genesis}

The strongest evidence for the role of Wnt signaling in thyroid cancer development is observed in familial thyroid cancer syndromes. Patients with Familial Adenomatous Polyposis (FAP), Gardner's syndrome, and Turcot's syndrome who carry a mutation in the APC gene have an increased risk of thyroid cancer, resulting in inappropriate Wnt pathway signaling $[52,53]$. These thyroid tumors, known as the cribiform-morular variant, have been shown to maintain heterozygosity of the APC mutation; however; they also carry stabilizing mutations of $\beta$-catenin as well as RET-PTC rearrangements [54-56]. RET-PTC fusions, frequently RET-PTC1 and RET-PTC3, are common in PTC. RET-PTC fusions lead to constitutive activation of the oncogene, RET, and stimulation of the MAPK and PI3K-AKT pathways [57,58]. Recent studies indicate that RET-PTC fusions also trigger the Wnt pathway by phosphorylating $\beta$-catenin at the Y654 tyrosine residue and inhibiting its turnover $[59,60]$. The genetic 
alterations identified in familial thyroid cancer syndromes strongly support a role for aberrant Wnt signaling in thyroid cancer development. However, the mutational landscape of thyroid cancer is complex, and the involvement of Wnt signaling in each thyroid cancer subtype will need to be clearly defined.

Well-differentiated thyroid carcinomas, such as PTC, represent some of the most common and least aggressive thyroid cancers. The metastatic activity of PTC has been shown to be dependent on E-cadherin downregulation and elevated levels of $\beta$-catenin [61]. PTCs are driven by three main genetic alterations: $\mathrm{BRAF}^{\mathrm{V} 600 \mathrm{E}}$ mutation, RET/PTC fusion, and RAS mutation (Table 2). Recent studies demonstrate that all three genetic subtypes ultimately stimulate the Wnt pathway via distinct mechanisms to promote tumorigenesis (Figure 4). As described above, RET-PTC fusion stimulates the Wnt pathway by promoting the stabilization of $\beta$-catenin $[59,60,62]$.

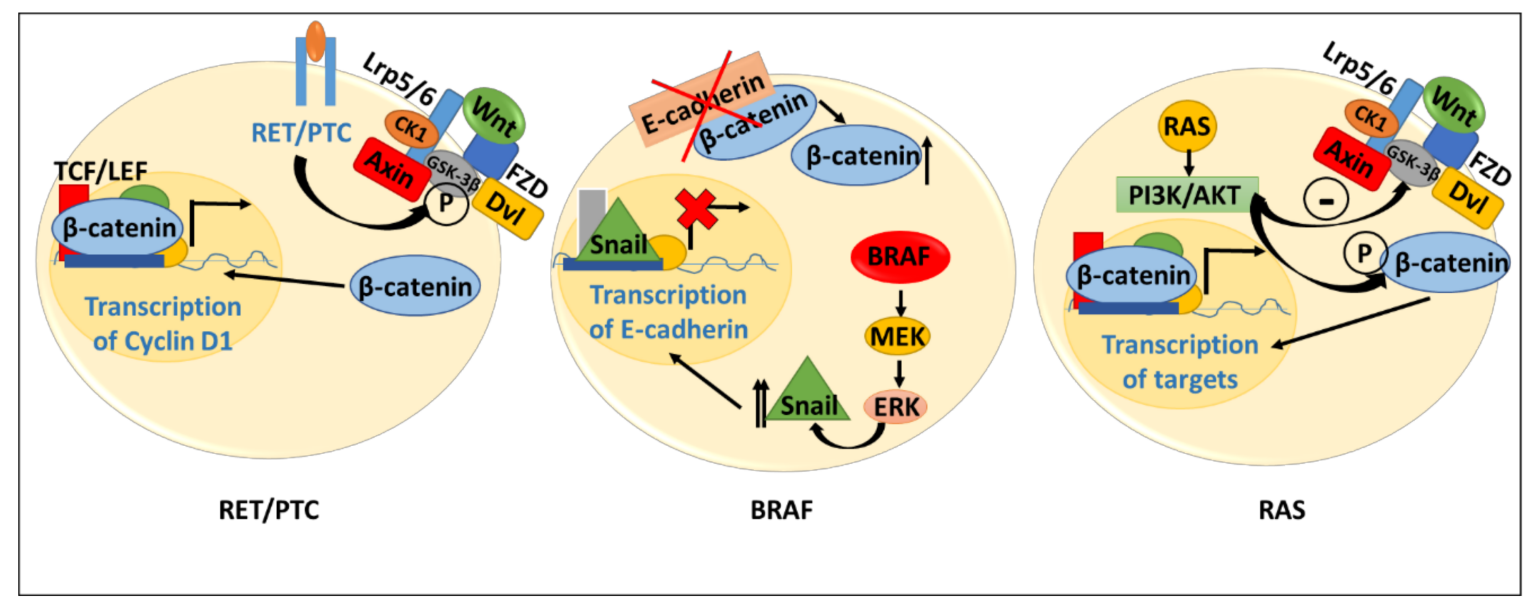

Figure 4. Proposed role of Wnt signaling in current papillary thyroid carcinomas (PTCs) with common driver mutations/alterations. In tumors with RET/PTC fusions, RET/PTC promotes the stabilization of $\beta$-catenin though phosphorylation of GSK-3 $\beta$. This allows $\beta$-catenin to traffic to the nucleus and interact with TCF/LEF to promote cyclin D1 transcription. In tumors with BRAFV600E mutation, $\mathrm{BRAF}^{\mathrm{V} 600 \mathrm{E}}$ is constitutively active and its signaling leads to an increased expression of Snail. Snail then acts to inhibit the transcription of E-cadherin by binding to the promoter and acting as a repressor. The decreased E-cadherin expression at the membrane leads to increased cytoplasmic $\beta$-catenin. Finally, in RAS-mutated tumors, RAS signaling through PI3K/AKT leads to stabilization of $\beta$-catenin through phosphorylation and through inhibition of GSK-3 $\beta$. This allows $\beta$-catenin to traffic to the nucleus and promote transcription of target genes.

BRAF-driven tumors have also been speculated to rely on Wnt signaling, although the details of this interaction remain to be determined. The $\mathrm{BRAF}^{\mathrm{V} 600 \mathrm{E}}$ mutation has been shown to activate the MAPK/ERK pathway, and there is evidence of cross-talk between MAPK/ERK signaling and the Wnt pathway in several tumor types, including lung cancer and melanoma [63-65]. In thyroid tumors, elucidation of the interaction between BRAF and Wnt signaling is just beginning to emerge, and BRAF mutations in PTC appear to cause downregulation of E-cadherin, potentially promoting Wnt signaling via a mechanism involving increased levels of cytoplasmic $\beta$-catenin [66]. Perhaps more convincing is the study by Park et al. of gene expression in The Cancer Genome Atlas, in which they observed that PTCs with extrathyroidal tumor extension exhibited aberrant Wnt pathway expression as evidenced by upregulation of SFRP2, SFRP4, Wnt-7A, and Wnt-2 and downregulation of Wnt-4 [67]. As BRAF mutations are associated with more frequent extrathyroidal extension, a correlation between Wnt- 4 and mutational phenotype was evaluated. They found that Wnt- 4 was reduced in BRAF mutant tumors, but unchanged in RAS mutant samples [67]. 
RAS-driven thyroid tumors have been proposed to regulate canonical (Wnt/ $\beta$-catenin) and non-canonical Wnt signaling via multiple mechanisms. In contrast to the study by Park et al. that found Wnt-4 expression to be unchanged in RAS-mutant tumors, De Menna et al. demonstrated Wnt-4 downregulation by RAS [68]. This group showed enhanced rat thyrocyte motility following expression of oncogenic RAS that strongly correlated with Wnt-4 downregulation. Conversely, expression of Wnt-4 inhibited RAS-dependent motility. The authors suggested that RAS-mediated suppression of Wnt- 4 was due to induction of miR-24 by RAS [68].

In thyroid tumors driven by RAS mutation, activation of PI3K/AKT caused a reduction in E-cadherin levels, increased nuclear $\beta$-catenin localization, and activation of the Wnt pathway. Nuclear localization of $\beta$-catenin was proposed to be mediated by its phosphorylation by AKT at Ser552. The role of Wnt signaling in thyroid cancer cell growth was confirmed by the demonstration that short hairpin RNA (shRNA)-mediated silencing of $\beta$-catenin resulted in decreased proliferation and promotion of cellular senescence as measured by an increase in $\beta$-galactosidase activity [69]. Finally, Cho et al. showed that the soluble inhibitor, Dickkopf-1, could block survival and migration of PTC cells via inhibition of Wnt signaling and E-cadherin upregulation [70].

Follicular thyroid carcinoma (FTC), another well-differentiated carcinoma, has also been found to be regulated by Wnt signaling. Using the mutant $\mathrm{TR} \beta^{\mathrm{PV} / \mathrm{PV}}$ mouse model of FTC, it was demonstrated that Wnt signaling is elevated in FTC via a mechanism involving stabilization of $\beta$-catenin as described earlier. In addition, the TR $\beta^{\mathrm{PV} / \mathrm{PV}}$ mutant was also shown to interact with PI3K to activate AKT signaling [71] to promote the phosphorylation of $\beta$-catenin at Ser522, thereby enhancing its cytoplasmic and nuclear accumulation [72]. TR $\beta^{\mathrm{PV} / \mathrm{PV}}$ mice also have increased $\mathrm{TH}$ levels, which has been suggested to further activate AKT in these tumors. Elevated T3 is proposed to bind to the TH membrane receptor, integrin $\alpha v \beta 3$, so as to promote extranuclear signaling [73]. Lu et al. hypothesized that integrin $\alpha \mathrm{v} \beta 3$ signaling leads to decreased PTEN activity, increased PIP3, increased phosphorylated AKT, and ultimately enhanced Ser522 $\beta$-catenin phosphorylation [72].

Anaplastic thyroid carcinomas (ATC) are some of the most aggressive and lethal cancers. These cancers exhibit p53 pathway deregulation and stabilizing $\beta$-catenin (CTNNB1) mutations, which contribute to their aggressive behavior (Table 2) [74]. In one investigation involving 22 patients with ATC, $\sim 40 \%$ of the tumors were reported to have nuclear $\beta$-catenin staining. Furthermore, $4.1 \%$ of tumors had stabilizing $\beta$-catenin mutations, $9.0 \%$ had APC mutations, and $\sim 82 \%$ had Axin mutations [75]. Several groups have shown that $\beta$-catenin and E-cadherin functions are essential for ATC survival and migration. Indeed, loss of E-cadherin expression has been found to be a poor prognostic marker in thyroid cancer $[76,77]$. A study of ATC cell lines demonstrated that addition of the tyrosine kinase inhibitor, imatinib mesylate, led to decreased $\beta$-catenin, increased $\beta$-catenin/E-cadherin complex formation, and diminished aggressive tumor behavior [78]. The classical non-canonical Wnt ligands, Wnt-5a and Wnt-4 [79], have been shown to play a role in anaplastic thyroid carcinoma malignancy. Wnt-5a normally is expressed in follicular adenomas and well-differentiated thyroid carcinomas, such as PTC and FTC, and has been proposed to act as a tumor suppressor [80]. Loss of Wnt-5a expression, as is often seen in ATC, is associated with a more aggressive, malignant phenotype [80]. In addition, Wnt-4 is downregulated in ATC [68]. In summary, there is compelling evidence that thyroid carcinomas are dependent on Wnt signaling for growth and proliferation, with elevated levels of signaling associated with poorly differentiated disease. 
Table 2. Non-medullary thyroid cancer sub-types and their most common mutations/signaling pathways. Frequency: $>40 \%=+++; 10-40 \%=++;<10 \%=+$.

\begin{tabular}{|c|c|c|c|c|}
\hline Thyroid Cancer & Mutation/Alteration & Frequency & Signaling Pathways & References \\
\hline \multirow{7}{*}{$\begin{array}{l}\text { Papillary Thyroid } \\
\text { Carcinoma }\end{array}$} & BRAF & +++ & MAPK & \multirow{7}{*}{$\begin{array}{c}\text { Nikiforov } 2008 \text { [81] } \\
\text { Ishigaki } 2002 \text { [82] } \\
\text { Garcia-Rostan } 2001 \text { [74] } \\
\text { Rezk } 2004 \text { [83] }\end{array}$} \\
\hline & RET/PTC & ++ & PI3K/AKT & \\
\hline & RAS & ++ & MAPK & \\
\hline & & & PI3K/AKT & \\
\hline & TRK & + & MAPK & \\
\hline & & & PI3K/AKT & \\
\hline & CTNNB1 dysregulation & ++ & Wnt Signaling & \\
\hline \multirow{6}{*}{$\begin{array}{c}\text { Follicular Thyroid } \\
\text { Carcinoma }\end{array}$} & RAS & +++ & MAPK & \multirow{6}{*}{$\begin{array}{c}\text { Nikiforov } 2008 \text { [81] } \\
\text { Farrow } 2003 \text { [84] } \\
\text { Garcia-Rostan 2001 [74] } \\
\text { Rezk 2004 [83] }\end{array}$} \\
\hline & & & PI3K/AKT & \\
\hline & PAX8-PPAR $\gamma$ & ++ & PI3K/AKT & \\
\hline & PIK3CA & + & PI3K/AKT & \\
\hline & PTEN & + & PI3K/AKT & \\
\hline & CTNNB1 dysregulation & ++ & Wnt Signaling & \\
\hline \multirow{5}{*}{$\begin{array}{l}\text { Poorly Differentiated } \\
\text { Thyroid Carcinoma }\end{array}$} & RAS & ++ & MAPK & \multirow{5}{*}{$\begin{array}{c}\text { Nikiforov } 2008 \text { [81] } \\
\text { Garcia-Rostan } 2001 \text { [74] }\end{array}$} \\
\hline & & & PI3K/AKT & \\
\hline & CTNNB1 & ++ & Wnt signaling & \\
\hline & TP53 & ++ & p53 signaling & \\
\hline & BRAF & ++ & MAPK & \\
\hline \multirow{6}{*}{$\begin{array}{l}\text { Anaplastic Thyroid } \\
\text { Carcinoma }\end{array}$} & TP53 & +++ & p53 signaling & \multirow{6}{*}{$\begin{array}{c}\text { Nikiforov } 2008[81] \\
\text { Kurihara } 2004[75] \\
\text { Garcia-Rostan } 2001[74]\end{array}$} \\
\hline & CTNNB1 & +++ & Wnt signaling & \\
\hline & AXIN & +++ & Wnt signaling & \\
\hline & RAS & +++ & MAPK & \\
\hline & & & PI3K/AKT & \\
\hline & BRAF & ++ & MAPK & \\
\hline
\end{tabular}

\subsection{Evidence for Thyroid Cancer Stem Cells}

Thyroid "cancer stem cells" have been an important area of research and a topic of debate. Indeed, these cancer cells with stem-cell-like properties are thought to be responsible for tumor growth and, due to their resistance to chemotherapeutic agents, are also believed to be responsible for tumor recurrence. The existence of such cancer cells with a progenitor phenotype in thyroid tumors has not yet been proven, but data are beginning to emerge indicating that they may indeed be crucial for thyroid cancer pathogenesis. There are multiple hypotheses regarding the origin of cancer stem cells in the thyroid. One is that well-differentiated thyroid cancer cells transform into more de-differentiated cell types through a series of mutations and possibly epithelial-to-mesenchymal transition $[34,85]$. Another proposes that thyroid cancer arises from residual fetal cells with stem-cell marker expression that reside within solid cell nests in the thyroid [34,86-88]. The third model suggests that cancer stem cells could arise from resident thyroid stem cells that accumulate a series of genetic alterations $[89,90]$. This theory has gained considerable attention in recent years and is particularly attractive as it combines the concept of cancer stem cells with the model of multiple mutational events leading to cancer. This would also explain why studies of more aggressive thyroid cancer subtypes have more genetic alterations and more malignant behavior.

Much attention has focused on the search for stem cells within previously characterized thyroid cancer cell lines. Side population cells (described above) that exhibit stem-cell characteristics and can give rise to both side population and non-side population cells have been described. For example, one study identified an Oct-4+ side population of cells within an anaplastic thyroid carcinoma that were multi-drug resistant due to the ABCG2 multi-drug resistance transporter [91]. Evaluation of the gene expression of these side population cells by quantitative real-time RT-PCR revealed increased expression of FZD5, a receptor for Wnt-5a in the non-canonical Wnt pathway, as compared to non-side population cells [48].

\subsection{Wht Signaling in Thyroid Cancer Stem Cells}

While studies of driver mutations in thyroid cancer have implicated Wnt signaling in pathogenesis, estrogen stimulation may also activate Wnt signaling. Although both women and men rely on TH for homeostasis, women have a substantially higher burden of thyroid disease as well as a higher 
incidence of thyroid cancer. One reason for this disparity involves the difference in hormone expression and regulation in males versus females. Circulating estrogens are thought to increase thyroid disease in women through their activation of the PI3K pathway and repression of p27 expression [92]. Reports suggest that estrogen stimulation also regulates thyroid cancer stem cell function. Xu et al. demonstrated that stem cells from thyroid goiters had enhanced organoid formation with stimulation by $17 \beta$-estradiol (E2) [93]. One potential mechanism may be via the Wnt pathway, as Koumenko et al. have described the interaction of $\beta$-catenin with an estrogen receptor, ER- $\alpha$, in connecting estrogen stimulation to Wnt activation [94]. Specifically, this group found that ER- $\alpha$ and $\beta$-catenin existed in the same immunocomplexes and were reciprocally recruited to the promoters of target genes. Consistent with these findings, other studies have suggested that E2 stimulation is associated with increased $\beta$-catenin levels as well as increased invasion and migration of thyroid tumors [95]. A model of estrogen-stimulated Wnt pathway activation in thyroid stem cells is particularly attractive, as Wnt signaling is a critical regulator of cancer pathogenesis in other organs, and its stimulation by estrogen could help to explain the gender disparity of thyroid disease.

Thyroid cancer stem cells may arise from differentiated thyroid cancer cells that undergo epithelial-to-mesenchymal transition (EMT) to a de-differentiated state via a mechanism involving the Wnt pathway. Lan et al. proposed that EMT could be induced through HIF-1 $\alpha$ and that activation of the Wnt signaling pathway accompanied this transition [85]. While this model may not represent the true origin of thyroid cancer stem cells, it highlights the importance of Wnt signaling in the maintenance of thyroid cancer progenitor cells. Todaro et al. reported the most convincing evidence for the role of Wnt signaling in thyroid cancer stem cells. They identified progenitor cells with stem-cell-like properties within thyroid cancer cell lines and found that these cells accumulated nuclear $\beta$-catenin and possessed a migratory capability. Indeed, cells with increased migration showed nuclear $\beta$-catenin and a loss of E-cadherin [16].

\section{Conclusions}

A considerable body of work published in recent years has enhanced our understanding of thyroid stem cell biology. There is now convincing evidence for the existence of adult stem cells in the thyroid gland. These cells are likely responsible for thyroid regeneration following hemi-thyroidectomy or injury from autoimmune attack and emerging data suggest that Wnt signaling is likely required for their maintenance. Further investigation is needed to delineate the precise location of these stem cells within thyroid tissue, the timing and function of Wnt signaling within these stem cells, and the source of the Wnt ligands.

Recent studies on thyroid cancer stem cells have also provided evidence for their potential roles in metastasis and recurrence. Indeed, while most thyroid cancer is cured following standard therapy, a subset of patients has metastatic and/or recurrent aggressive disease that is driven, at least to some extent, by Wnt signaling, although the exact role of this pathway in each thyroid cancer subtype remains unclear. Stem-cell markers, such as Lgr5 (also a Wnt target gene), may be useful for locating thyroid cancer stem cells in order to verify their presence and disclose their organization within thyroid tumors.

Modulation of Wnt signaling within both normal and neoplastic thyroid tissue may help to further define the role of this signaling pathway in thyroid homeostasis and malignancy. Targeting Wnt in patients with thyroid disease could have tremendous implications for therapy. Small molecule Wnt activators, such as lithium (a GSK-3 $\beta$ inhibitor), could increase stem cell function and lead to thyroid tissue regeneration following surgery or autoimmune injury. Lithium chloride ( $\mathrm{LiCl})$ is known to cause thyroid tissue growth and goiter formation [96-98]. This effect is due, at least in part, to stimulation of the Wnt pathway [98]. However, increased thyroid tissue is not desirable if it is not producing thyroid hormone. As lithium is also known to inhibit the synthesis, release, and deiodination of thyroid hormone, its administration and stimulation of thyroid growth may not lead to decreased hypothyroidism $[96,99]$. In addition, Wnt blockade, rather than enhancement, may be 
critical in Hashimoto's disease, as these patients have a higher risk of developing thyroid cancer. In fact, the inhibition of Wnt signaling in patients with longstanding Hashimoto's thyroiditis may be an important strategy for the prevention of thyroid malignancy. Additional research is needed to understand the complex role of Wnt signaling in thyroid stem cell biology and thyroid homeostasis and improve the treatment of thyroid disease.

Given the accumulating evidence for Wnt signaling in thyroid cancer (particularly the aggressive and malignant forms), a thorough evaluation of the roles of Wnt signaling in thyroid tumor progression is needed. Demonstration that Wnt signaling plays a role in thyroid cancer can be readily performed by simple knockdown/knockout studies with RNA interference (RNAi) or CRISPR/Cas9 editing technologies. Alternatively, various small molecule inhibitors have been developed that are in various stages of clinical trials, including Wnt ligand inhibitors (currently in Phase I Clinical Trials) [100] and antagonists of the TCF/ $\beta$-catenin transcriptional complex (currently in Phase I/II Clinical Trials) [101]. These inhibitors could be tested for their capacity to inhibit thyroid cancer growth and metastasis in cell-based and animal models. Perhaps the most promising use of Wnt inhibitors may be for patients with extremely treatment-resistant anaplastic thyroid carcinomas which carry activating Wnt pathway gene mutations. Anaplastic thyroid carcinomas patients have an abysmal survival rate (4 months), and anti-Wnt therapy may be particularly beneficial to this subset of thyroid cancer patients. In conclusion, Wnt blockade in thyroid cancer stem cells has great potential to provide critical information on tumorigenesis and to inform strategies for targeting these cells in thyroid cancer treatment.

Conflicts of Interest: The authors declare no conflict of interest.

\section{References}

1. Barker, N.; Huch, M.; Kujala, P.; van de Wetering, M.; Snippert, H.J.; van Es, J.H.; Sato, T.; Stange, D.E.; Begthel, H.; van den Born, M.; et al. Lgr5 ${ }^{+v e}$ stem cells drive self-renewal in the stomach and build long-lived gastric units in vitro. Cell Stem Cell 2010, 6, 25-36. [CrossRef]

2. Biteau, B.; Hochmuth, C.E.; Jasper, H. Maintaining tissue homeostasis: Dynamic control of somatic stem cell activity. Cell Stem Cell 2011, 9, 402-411. [CrossRef]

3. Wilson, A.; Laurenti, E.; Oser, G.; van der Wath, R.C.; Blanco-Bose, W.; Jaworski, M.; Offner, S.; Dunant, C.F.; Eshkind, L.; Bockamp, E.; et al. Hematopoietic stem cells reversibly switch from dormancy to self-renewal during homeostasis and repair. Cell 2008, 135, 1118-1129. [CrossRef]

4. Fleming, H.E.; Janzen, V.; Lo Celso, C.; Guo, J.; Leahy, K.M.; Kronenberg, H.M.; Scadden, D.T. Wnt signaling in the niche enforces hematopoietic stem cell quiescence and is necessary to preserve self-renewal in vivo. Cell Stem Cell 2008, 2, 274-283. [CrossRef]

5. Reya, T.; Duncan, A.W.; Ailles, L.; Domen, J.; Scherer, D.C.; Willert, K.; Hintz, L.; Nusse, R.; Weissman, I.L. A role for Wnt signalling in self-renewal of haematopoietic stem cells. Nature 2003, 423, 409-414. [CrossRef] [PubMed]

6. Willert, K.; Brown, J.D.; Danenberg, E.; Duncan, A.W.; Weissman, I.L.; Reya, T.; Yates, J.R., 3rd; Nusse, R. Wnt proteins are lipid-modified and can act as stem cell growth factors. Nature 2003, 423, 448-452. [CrossRef]

7. Sastre-Perona, A.; Santisteban, P. Role of the Wnt pathway in thyroid cancer. Front. Endocrinol. (Lausanne) 2012, 3, 31. [CrossRef]

8. Sastre-Perona, A.; Santisteban, P. Wnt-independent role of $\beta$-catenin in thyroid cell proliferation and differentiation. Mol. Endocrinol. 2014, 28, 681-695. [CrossRef]

9. Garber, J.R.; Cobin, R.H.; Gharib, H.; Hennessey, J.V.; Klein, I.; Mechanick, J.I.; Pessah-Pollack, R.; Singer, P.A.; Woeber, K.A. American Association of Clinical Endocrinologists and American Thyroid Association Taskforce on Hypothyroidism in Adults. Clinical practice guidelines for hypothyroidism in adults: Cosponsored by the American Association of Clinical Endocrinologists and the American Thyroid Association. Endocr. Pract. 2012, 18, 988-1028.

10. Yen, P.M. Physiological and molecular basis of thyroid hormone action. Physiol. Rev. 2001, 81, 1097-1142. [CrossRef] 
11. Wu, Y.; Xu, B.; Koenig, R.J. Thyroid hormone response element sequence and the recruitment of retinoid X receptors for thyroid hormone responsiveness. J. Biol. Chem. 2001, 276, 3929-3936. [CrossRef]

12. Dentice, M.; Marsili, A.; Zavacki, A.; Larsen, P.R.; Salvatore, D. The deiodinases and the control of intracellular thyroid hormone signaling during cellular differentiation. Biochim. Biophys. Acta 2013, 1830, 3937-3945. [CrossRef] [PubMed]

13. Williams, A.J.; Robson, H.; Kester, M.H.; van Leeuwen, J.P.; Shalet, S.M.; Visser, T.J.; Williams, G.R. Iodothyronine deiodinase enzyme activities in bone. Bone 2008, 43, 126-134. [CrossRef]

14. Gereben, B.; Zeold, A.; Dentice, M.; Salvatore, D.; Bianco, A.C. Activation and inactivation of thyroid hormone by deiodinases: Local action with general consequences. Cell Mol. Life Sci. 2008, 65, 570-590. [CrossRef] [PubMed]

15. Cheng, S.Y.; Leonard, J.L.; Davis, P.J. Molecular aspects of thyroid hormone actions. Endocr. Rev. 2010, 31, 139-170. [CrossRef] [PubMed]

16. Todaro, M.; Iovino, F.; Eterno, V.; Cammareri, P.; Gambara, G.; Espina, V.; Gulotta, G.; Dieli, F.; Giordano, S.; De Maria, R.; et al. Tumorigenic and metastatic activity of human thyroid cancer stem cells. Cancer Res. 2010, 70, 8874-8885. [CrossRef] [PubMed]

17. Guigon, C.J.; Zhao, L.; Lu, C.; Willingham, M.C.; Cheng, S.Y. Regulation of $\beta$-catenin by a novel nongenomic action of thyroid hormone $\beta$ receptor. Mol. Cell Biol. 2008, 28, 4598-4608. [CrossRef]

18. Dentice, M.; Luongo, C.; Ambrosio, R.; Sibilio, A.; Casillo, A.; Iaccarino, A.; Troncone, G.; Fenzi, G.; Larsen, P.R.; Salvatore, D. $\beta$-Catenin regulates deiodinase levels and thyroid hormone signaling in colon cancer cells. Gastroenterology 2012, 143, 1037-1047. [CrossRef]

19. Brown, A.R.; Simmen, R.C.; Simmen, F.A. The role of thyroid hormone signaling in the prevention of digestive system cancers. Int. J. Mol. Sci. 2013, 14, 16240-16257. [CrossRef]

20. Saito-Diaz, K.; Chen, T.W.; Wang, X.; Thorne, C.A.; Wallace, H.A.; Page-McCaw, A.; Lee, E. The way Wnt works: Components and mechanism. Growth Factors 2013, 31, 1-31. [CrossRef]

21. Ng, L.; Lyubarsky, A.; Nikonov, S.S.; Ma, M.; Srinivas, M.; Kefas, B.; St Germain, D.L.; Hernandez, A.; Pugh, E.N., Jr.; Forrest, D. Type 3 deiodinase, a thyroid-hormone-inactivating enzyme, controls survival and maturation of cone photoreceptors. J. Neurosci. 2010, 30, 3347-3357. [CrossRef]

22. Dentice, M.; Salvatore, D. Deiodinases: The balance of thyroid hormone: Local impact of thyroid hormone inactivation. J. Endocrinol. 2011, 209, 273-282. [CrossRef] [PubMed]

23. Dentice, M.; Antonini, D.; Salvatore, D. Type 3 deiodinase and solid tumors: An intriguing pair. Expert Opin. Ther. Targets 2013, 17, 1369-1379. [CrossRef] [PubMed]

24. Miller, L.D.; Park, K.S.; Guo, Q.M.; Alkharouf, N.W.; Malek, R.L.; Lee, N.H.; Liu, E.T.; Cheng, S.Y. Silencing of Wnt signaling and activation of multiple metabolic pathways in response to thyroid hormone-stimulated cell proliferation. Mol. Cell Biol. 2001, 21, 6626-6639. [CrossRef] [PubMed]

25. Sirakov, M.; Skah, S.; Nadjar, J.; Plateroti, M. Thyroid hormone's action on progenitor/stem cell biology: New challenge for a classic hormone? Biochim. Biophys. Acta 2013, 1830, 3917-3927. [CrossRef] [PubMed]

26. Natsume, H.; Sasaki, S.; Kitagawa, M.; Kashiwabara, Y.; Matsushita, A.; Nakano, K.; Nishiyama, K.; Nagayama, K.; Misawa, H.; Masuda, H.; et al. $\beta$-catenin/Tcf-1-mediated transactivation of cyclin D1 promoter is negatively regulated by thyroid hormone. Biochem. Biophys. Res. Commun. 2003, 309, 408-413. [CrossRef]

27. Bianco, A.C.; Kim, B.W. Deiodinases: Implications of the local control of thyroid hormone action. J. Clin. Investig. 2006, 116, 2571-2579. [CrossRef] [PubMed]

28. Heijlen, M.; Houbrechts, A.M.; Bagci, E.; Van Herck, S.L.; Kersseboom, S.; Esguerra, C.V.; Blust, R.; Visser, T.J.; Knapen, D.; Darras, V.M. Knockdown of type 3 iodothyronine deiodinase severely perturbs both embryonic and early larval development in zebrafish. Endocrinology 2014, 155, 1547-1559. [CrossRef]

29. Snippert, H.J.; van der Flier, L.G.; Sato, T.; van Es, J.H.; van den Born, M.; Kroon-Veenboer, C.; Barker, N.; Klein, A.M.; van Rheenen, J.; Simons, B.D.; et al. Intestinal crypt homeostasis results from neutral competition between symmetrically dividing Lgr5 stem cells. Cell 2010, 143, 134-144. [CrossRef]

30. Bienz, M.; Clevers, H. Linking colorectal cancer to Wnt signaling. Cell 2000, 103, 311-320. [CrossRef]

31. Thomas, T.; Nowka, K.; Lan, L.; Derwahl, M. Expression of endoderm stem cell markers: Evidence for the presence of adult stem cells in human thyroid glands. Thyroid 2006, 16, 537-544. [CrossRef] [PubMed] 
32. Chen, C.Y.; Kimura, H.; Landek-Salgado, M.A.; Hagedorn, J.; Kimura, M.; Suzuki, K.; Westra, W.; Rose, N.R.; Caturegli, P. Regenerative potentials of the murine thyroid in experimental autoimmune thyroiditis: Role of CD24. Endocrinology 2009, 150, 492-499. [CrossRef]

33. Mauchamp, J.; Mirrione, A.; Alquier, C.; Andre, F. Follicle-like structure and polarized monolayer: Role of the extracellular matrix on thyroid cell organization in primary culture. Biol Cell 1998, 90, 369-380. [CrossRef]

34. Davies, T.F.; Latif, R.; Minsky, N.C.; Ma, R. Clinical review: The emerging cell biology of thyroid stem cells. J. Clin. Endocrinol. Metab. 2011, 96, 2692-2702. [CrossRef]

35. Nilsson, M.; Fagman, H. Development of the thyroid gland. Development 2017, 144, 2123-2140. [CrossRef] [PubMed]

36. Postiglione, M.P.; Parlato, R.; Rodriguez-Mallon, A.; Rosica, A.; Mithbaokar, P.; Maresca, M.; Marians, R.C.; Davies, T.F.; Zannini, M.S.; De Felice, M.; et al. Role of the thyroid-stimulating hormone receptor signaling in development and differentiation of the thyroid gland. Proc. Natl. Acad. Sci. USA 2002, 99, 15462-15467. [CrossRef] [PubMed]

37. Marians, R.C.; Ng, L.; Blair, H.C.; Unger, P.; Graves, P.N.; Davies, T.F. Defining thyrotropin-dependent and -independent steps of thyroid hormone synthesis by using thyrotropin receptor-null mice. Proc. Natl. Acad. Sci. USA 2002, 99, 15776-15781. [CrossRef]

38. Xu, P.X.; Zheng, W.; Laclef, C.; Maire, P.; Maas, R.L.; Peters, H.; Xu, X. Eya1 is required for the morphogenesis of mammalian thymus, parathyroid and thyroid. Development 2002, 129, 3033-3044.

39. Kurihara, Y.; Kurihara, H.; Maemura, K.; Kuwaki, T.; Kumada, M.; Yazaki, Y. Impaired development of the thyroid and thymus in endothelin-1 knockout mice. J. Cardiovasc. Pharmacol. 1995, 26 (Suppl. 3), S13-S16. [CrossRef]

40. Kurmann, A.A.; Serra, M.; Hawkins, F.; Rankin, S.A.; Mori, M.; Astapova, I.; Ullas, S.; Lin, S.; Bilodeau, M.; Rossant, J.; et al. Regeneration of thyroid function by transplantation of differentiated pluripotent stem cells. Cell Stem Cell 2015, 17, 527-542. [CrossRef] [PubMed]

41. Elsalini, O.A.; von Gartzen, J.; Cramer, M.; Rohr, K.B. Zebrafish hhex, nk2.1a, and pax2.1 regulate thyroid growth and differentiation downstream of Nodal-dependent transcription factors. Dev. Biol. 2003, 263, 67-80. [CrossRef]

42. Meeus, L.; Gilbert, B.; Rydlewski, C.; Parma, J.; Roussie, A.L.; Abramowicz, M.; Vilain, C.; Christophe, D.; Costagliola, S.; Vassart, G. Characterization of a novel loss of function mutation of PAX8 in a familial case of congenital hypothyroidism with in-place, normal-sized thyroid. J. Clin. Endocrinol. Metab. 2004, 89, 4285-4291. [CrossRef]

43. De Felice, M.; Ovitt, C.; Biffali, E.; Rodriguez-Mallon, A.; Arra, C.; Anastassiadis, K.; Macchia, P.E.; Mattei, M.G.; Mariano, A.; Scholer, H.; et al. A mouse model for hereditary thyroid dysgenesis and cleft palate. Nat. Genet. 1998, 19, 395-398. [CrossRef] [PubMed]

44. Clifton-Bligh, R.J.; Wentworth, J.M.; Heinz, P.; Crisp, M.S.; John, R.; Lazarus, J.H.; Ludgate, M.; Chatterjee, V.K. Mutation of the gene encoding human TTF-2 associated with thyroid agenesis, cleft palate and choanal atresia. Nat. Genet. 1998, 19, 399-401. [CrossRef]

45. Antonica, F.; Kasprzyk, D.F.; Opitz, R.; Iacovino, M.; Liao, X.H.; Dumitrescu, A.M.; Refetoff, S.; Peremans, K.; Manto, M.; Kyba, M.; et al. Generation of functional thyroid from embryonic stem cells. Nature 2012, 491, 66-71. [CrossRef]

46. Dumont, J.E.; Lamy, F.; Roger, P.; Maenhaut, C. Physiological and pathological regulation of thyroid cell proliferation and differentiation by thyrotropin and other factors. Physiol. Rev. 1992, 72, 667-697. [CrossRef]

47. Watanabe, H.; Gould, M.N.; Mahler, P.A.; Mulcahy, R.T.; Clifton, K.H. The influence of donor and recipient age and sex on the quantitative transplantation of monodispersed rat thyroid cells. Endocrinology 1983, 112, 172-177. [CrossRef] [PubMed]

48. Mitsutake, N.; Iwao, A.; Nagai, K.; Namba, H.; Ohtsuru, A.; Saenko, V.; Yamashita, S. Characterization of side population in thyroid cancer cell lines: Cancer stem-like cells are enriched partly but not exclusively. Endocrinology 2007, 148, 1797-1803. [CrossRef]

49. Helmbrecht, K.; Kispert, A.; von Wasielewski, R.; Brabant, G. Identification of a Wnt/ $\beta$-catenin signaling pathway in human thyroid cells. Endocrinology 2001, 142, 5261-5266. [CrossRef] 
50. Chen, G.; Jiang, Q.; You, Z.; Yao, J.; Mou, L.; Lin, X.; Shen, X.; You, T.; Lin, Q.; Wen, J.; et al. Regulation of GSK-3 beta in the proliferation and apoptosis of human thyrocytes investigated using a GSK-3 beta-targeting RNAi adenovirus expression vector: Involvement the Wnt/beta-catenin pathway. Mol. Biol. Rep. 2010, 37, 2773-2779. [CrossRef]

51. Uhlen, M.; Fagerberg, L.; Hallstrom, B.M.; Lindskog, C.; Oksvold, P.; Mardinoglu, A.; Sivertsson, A.; Kampf, C.; Sjostedt, E.; Asplund, A.; et al. Proteomics. Tissue-based map of the human proteome. Science 2015, 347, 1260419. [CrossRef] [PubMed]

52. Soravia, C.; Sugg, S.L.; Berk, T.; Mitri, A.; Cheng, H.; Gallinger, S.; Cohen, Z.; Asa, S.L.; Bapat, B.V. Familial adenomatous polyposis-associated thyroid cancer: A clinical, pathological, and molecular genetics study. Am. J. Pathol. 1999, 154, 127-135. [CrossRef]

53. Kurihara, K.; Shimizu, S.; Chong, J.; Hishima, T.; Funata, N.; Kashiwagi, H.; Nagai, H.; Miyaki, M.; Fukayama, M. Nuclear localization of immunoreactive $\beta$-catenin is specific to familial adenomatous polyposis in papillary thyroid carcinoma. Jpn. J. Cancer Res. 2000, 91, 1100-1102. [CrossRef]

54. Xu, B.; Yoshimoto, K.; Miyauchi, A.; Kuma, S.; Mizusawa, N.; Hirokawa, M.; Sano, T. Cribriform-morular variant of papillary thyroid carcinoma: A pathological and molecular genetic study with evidence of frequent somatic mutations in exon 3 of the $\beta$-catenin gene. J. Pathol. 2003, 199, 58-67. [CrossRef] [PubMed]

55. Cetta, F.; Chiappetta, G.; Melillo, R.M.; Petracci, M.; Montalto, G.; Santoro, M.; Fusco, A. The ret/ptc1 oncogene is activated in familial adenomatous polyposis-associated thyroid papillary carcinomas. J. Clin. Endocrinol. Metab. 1998, 83, 1003-1006. [CrossRef] [PubMed]

56. Cetta, F.; Montalto, G.; Gori, M.; Curia, M.C.; Cama, A.; Olschwang, S. Germline mutations of the APC gene in patients with familial adenomatous polyposis-associated thyroid carcinoma: Results from a European cooperative study. J. Clin. Endocrinol. Metab. 2000, 85, 286-292. [PubMed]

57. Xing, M. Molecular pathogenesis and mechanisms of thyroid cancer. Nat. Rev. Cancer 2013, 13, 184-199. [CrossRef] [PubMed]

58. Nikiforov, Y.E. RET/PTC rearrangement in thyroid tumors. Endocr. Pathol. 2002, 13, 3-16. [CrossRef]

59. Cassinelli, G.; Favini, E.; Degl'Innocenti, D.; Salvi, A.; De Petro, G.; Pierotti, M.A.; Zunino, F.; Borrello, M.G.; Lanzi, C. RET/PTC1-driven neoplastic transformation and proinvasive phenotype of human thyrocytes involve Met induction and $\beta$-catenin nuclear translocation. Neoplasia 2009, 11, 10-21. [CrossRef] [PubMed]

60. Tartari, C.J.; Donadoni, C.; Manieri, E.; Mologni, L.; Mina, P.D.; Villa, A.; Gambacorti-Passerini, C. Dissection of the RET/ $\beta$-catenin interaction in the TPC1 thyroid cancer cell line. Am. J. Cancer Res. 2011, 1, 716-725. [PubMed]

61. Dong, W.; Zhang, H.; Li, J.; Guan, H.; He, L.; Wang, Z.; Shan, Z.; Teng, W. Estrogen induces metastatic potential of papillary thyroid cancer cells through estrogen receptor $\alpha$ and $\beta$. Int. J. Endocrinol. 2013, 2013, 941568. [CrossRef] [PubMed]

62. Castellone, M.D.; De Falco, V.; Rao, D.M.; Bellelli, R.; Muthu, M.; Basolo, F.; Fusco, A.; Gutkind, J.S.; Santoro, M. The $\beta$-catenin axis integrates multiple signals downstream from RET/papillary thyroid carcinoma leading to cell proliferation. Cancer Res. 2009, 69, 1867-1876. [CrossRef] [PubMed]

63. Bikkavilli, R.K.; Malbon, C.C. Mitogen-activated protein kinases and Wnt/ $\beta$-catenin signaling: Molecular conversations among signaling pathways. Commun. Integr. Biol. 2009, 2, 46-49. [CrossRef] [PubMed]

64. Juan, J.; Muraguchi, T.; Iezza, G.; Sears, R.C.; McMahon, M. Diminished WNT -> $\beta$-catenin $\rightarrow>$ c-MYC signaling is a barrier for malignant progression of $\mathrm{BRAF}^{\mathrm{V} 600 \mathrm{E}}$-induced lung tumors. Genes Dev. 2014, 28, 561-575. [CrossRef] [PubMed]

65. Damsky, W.E.; Curley, D.P.; Santhanakrishnan, M.; Rosenbaum, L.E.; Platt, J.T.; Gould Rothberg, B.E.; Taketo, M.M.; Dankort, D.; Rimm, D.L.; McMahon, M.; et al. $\beta$-catenin signaling controls metastasis in Braf-activated Pten-deficient melanomas. Cancer Cell 2011, 20, 741-754. [CrossRef] [PubMed]

66. Baquero, P.; Sanchez-Hernandez, I.; Jimenez-Mora, E.; Orgaz, J.L.; Jimenez, B.; Chiloeches, A. V600E BRAF promotes invasiveness of thyroid cancer cells by decreasing E-cadherin expression through a Snail-dependent mechanism. Cancer Lett. 2013, 335, 232-241. [CrossRef] [PubMed]

67. Park, J.Y.; Yi, J.W.; Park, C.H.; Lim, Y.; Lee, K.H.; Lee, K.E.; Kim, J.H. Role of BRAF and RAS mutations in extrathyroidal extension in papillary thyroid cancer. Cancer Genom. Proteom. 2016, 13, 171-181.

68. De Menna, M.; D’Amato, V.; Ferraro, A.; Fusco, A.; Di Lauro, R.; Garbi, C.; De Vita, G. Wnt4 inhibits cell motility induced by oncogenic Ras. Oncogene 2013, 32, 4110-4119. [CrossRef] [PubMed] 
69. Sastre-Perona, A.; Riesco-Eizaguirre, G.; Zaballos, M.A.; Santisteban, P. $\beta$-catenin signaling is required for RAS-driven thyroid cancer through PI3K activation. Oncotarget 2016, 7, 49435-49449. [CrossRef] [PubMed]

70. Cho, S.W.; Lee, E.J.; Kim, H.; Kim, S.H.; Ahn, H.Y.; Kim, Y.A.; Yi, K.H.; Park, D.J.; Shin, C.S.; Ahn, S.H.; et al. Dickkopf-1 inhibits thyroid cancer cell survival and migration through regulation of $\beta$-catenin/E-cadherin signaling. Mol. Cell Endocrinol. 2013, 366, 90-98. [CrossRef] [PubMed]

71. Furuya, F.; Hanover, J.A.; Cheng, S.Y. Activation of phosphatidylinositol 3-kinase signaling by a mutant thyroid hormone $\beta$ receptor. Proc. Natl. Acad. Sci. USA 2006, 103, 1780-1785. [CrossRef]

72. Lu, C.; Zhu, X.; Willingham, M.C.; Cheng, S.Y. Activation of tumor cell proliferation by thyroid hormone in a mouse model of follicular thyroid carcinoma. Oncogene 2012, 31, 2007-2016. [CrossRef]

73. Bergh, J.J.; Lin, H.Y.; Lansing, L.; Mohamed, S.N.; Davis, F.B.; Mousa, S.; Davis, P.J. Integrin $\alpha$ V $\beta 3$ contains a cell surface receptor site for thyroid hormone that is linked to activation of mitogen-activated protein kinase and induction of angiogenesis. Endocrinology 2005, 146, 2864-2871. [CrossRef]

74. Garcia-Rostan, G.; Camp, R.L.; Herrero, A.; Carcangiu, M.L.; Rimm, D.L.; Tallini, G. $\beta$-catenin dysregulation in thyroid neoplasms: Down-regulation, aberrant nuclear expression, and CTNNB1 exon 3 mutations are markers for aggressive tumor phenotypes and poor prognosis. Am. J. Pathol. 2001, 158, 987-996. [CrossRef]

75. Kurihara, T.; Ikeda, S.; Ishizaki, Y.; Fujimori, M.; Tokumoto, N.; Hirata, Y.; Ozaki, S.; Okajima, M.; Sugino, K.; Asahara, T. Immunohistochemical and sequencing analyses of the Wnt signaling components in Japanese anaplastic thyroid cancers. Thyroid 2004, 14, 1020-1029. [CrossRef] [PubMed]

76. Cali, G.; Gentile, F.; Mogavero, S.; Pallante, P.; Nitsch, R.; Ciancia, G.; Ferraro, A.; Fusco, A.; Nitsch, L. $\mathrm{CDH} 16 / \mathrm{Ksp}$-cadherin is expressed in the developing thyroid gland and is strongly down-regulated in thyroid carcinomas. Endocrinology 2012, 153, 522-534. [CrossRef]

77. Brabant, G.; Hoang-Vu, C.; Cetin, Y.; Dralle, H.; Scheumann, G.; Molne, J.; Hansson, G.; Jansson, S.; Ericson, L.E.; Nilsson, M. E-cadherin: A differentiation marker in thyroid malignancies. Cancer Res. 1993, 53 , 4987-4993.

78. Rao, A.S.; Kremenevskaja, N.; von Wasielewski, R.; Jakubcakova, V.; Kant, S.; Resch, J.; Brabant, G. Wnt/ $\beta$-catenin signaling mediates antineoplastic effects of imatinib mesylate (Gleevec) in anaplastic thyroid cancer. J. Clin. Endocrinol. Metab. 2006, 91, 159-168. [CrossRef]

79. Du, S.J.; Purcell, S.M.; Christian, J.L.; McGrew, L.L.; Moon, R.T. Identification of distinct classes and functional domains of Wnts through expression of wild-type and chimeric proteins in Xenopus embryos. Mol. Cell Biol. 1995, 15, 2625-2634. [CrossRef]

80. Kremenevskaja, N.; von Wasielewski, R.; Rao, A.S.; Schofl, C.; Andersson, T.; Brabant, G. Wnt-5a has tumor suppressor activity in thyroid carcinoma. Oncogene 2005, 24, 2144-2154. [CrossRef] [PubMed]

81. Nikiforov, Y.E. Thyroid carcinoma: Molecular pathways and therapeutic targets. Mod. Pathol. 2008,21 (Suppl. 2), S37-S43. [CrossRef] [PubMed]

82. Ishigaki, K.; Namba, H.; Nakashima, M.; Nakayama, T.; Mitsutake, N.; Hayashi, T.; Maeda, S.; Ichinose, M.; Kanematsu, T.; Yamashita, S. Aberrant localization of $\beta$-catenin correlates with overexpression of its target gene in human papillary thyroid cancer. J. Clin. Endocrinol. Metab. 2002, 87, 3433-3440. [PubMed]

83. Rezk, S.; Brynes, R.K.; Nelson, V.; Thein, M.; Patwardhan, N.; Fischer, A.; Khan, A. $\beta$-Catenin expression in thyroid follicular lesions: Potential role in nuclear envelope changes in papillary carcinomas. Endocr. Pathol. 2004, 15, 329-337. [CrossRef] [PubMed]

84. Farrow, B.; Evers, B.M. Activation of PPAR $\gamma$ increases PTEN expression in pancreatic cancer cells. Biochem. Biophys. Res. Commun. 2003, 301, 50-53. [CrossRef]

85. Lan, L.; Luo, Y.; Cui, D.; Shi, B.Y.; Deng, W.; Huo, L.L.; Chen, H.L.; Zhang, G.Y.; Deng, L.L. Epithelial-mesenchymal transition triggers cancer stem cell generation in human thyroid cancer cells. Int. J. Oncol. 2013, 43, 113-120. [CrossRef] [PubMed]

86. Takano, T. Fetal cell carcinogenesis of the thyroid: A modified theory based on recent evidence. Endocr. J. 2014, 61, 311-320. [CrossRef]

87. Reis-Filho, J.S.; Preto, A.; Soares, P.; Ricardo, S.; Cameselle-Teijeiro, J.; Sobrinho-Simões, M. p63 expression in solid cell nests of the thyroid: Further evidence for a stem cell origin. Mod. Pathol. 2003, 16, 43-48. [CrossRef] [PubMed]

88. Preto, A.; Cameselle-Teijeiro, J.; Moldes-Boullosa, J.; Soares, P.; Cameselle-Teijeiro, J.F.; Silva, P.; Reis-Filho, J.S.; Reyes-Santías, R.M.; Alfonsín-Barreiro, N.; Forteza, J.; et al. Telomerase expression and proliferative activity suggest a stem cell role for thyroid solid cell nests. Mod. Pathol. 2004, 17, 819-826. [CrossRef] [PubMed] 
89. Thomas, D.; Friedman, S.; Lin, R.Y. Thyroid stem cells: Lessons from normal development and thyroid cancer. Endocr. Relat. Cancer 2008, 15, 51-58. [CrossRef]

90. Zane, M.; Catalano, V.; Scavo, E.; Bonanno, M.; Pelizzo, M.R.; Todaro, M.; Stassi, G. Estrogens and stem cells in thyroid cancer. Front. Endocrinol. (Lausanne) 2014, 5. [CrossRef] [PubMed]

91. Zheng, X.; Cui, D.; Xu, S.; Brabant, G.; Derwahl, M. Doxorubicin fails to eradicate cancer stem cells derived from anaplastic thyroid carcinoma cells: Characterization of resistant cells. Int. J. Oncol. 2010, 37, 307-315. [PubMed]

92. Antico-Arciuch, V.G.; Dima, M.; Liao, X.H.; Refetoff, S.; Di Cristofano, A. Cross-talk between PI3K and estrogen in the mouse thyroid predisposes to the development of follicular carcinomas with a higher incidence in females. Oncogene 2010, 29, 5678-5686. [CrossRef] [PubMed]

93. Xu, S.; Chen, G.; Peng, W.; Renko, K.; Derwahl, M. Oestrogen action on thyroid progenitor cells: Relevant for the pathogenesis of thyroid nodules? J. Endocrinol. 2013, 218, 125-133. [CrossRef] [PubMed]

94. Kouzmenko, A.P.; Takeyama, K.; Ito, S.; Furutani, T.; Sawatsubashi, S.; Maki, A.; Suzuki, E.; Kawasaki, Y.; Akiyama, T.; Tabata, T.; et al. Wnt/ $\beta$-catenin and estrogen signaling converge in vivo. J. Biol. Chem. 2004, 279, 40255-40258. [CrossRef] [PubMed]

95. Rajoria, S.; Suriano, R.; Shanmugam, A.; Wilson, Y.L.; Schantz, S.P.; Geliebter, J.; Tiwari, R.K. Metastatic phenotype is regulated by estrogen in thyroid cells. Thyroid 2010, 20, 33-41. [CrossRef] [PubMed]

96. Lazarus, J.H. Lithium and thyroid. Best Pract. Res. Clin. Endocrinol. Metab. 2009, 23, 723-733. [CrossRef] [PubMed]

97. Urabe, M.; Hershman, J.M.; Pang, X.P.; Murakami, S.; Sugawara, M. Effect of lithium on function and growth of thyroid cells in vitro. Endocrinology 1991, 129, 807-814. [CrossRef]

98. Rao, A.S.; Kremenevskaja, N.; Resch, J.; Brabant, G. Lithium stimulates proliferation in cultured thyrocytes by activating Wnt/ $\beta$-catenin signalling. Eur. J. Endocrinol. 2005, 153, 929-938. [CrossRef] [PubMed]

99. Lazarus, J.H. The effects of lithium therapy on thyroid and thyrotropin-releasing hormone. Thyroid 1998, 8 , 909-913. [CrossRef]

100. Liu, J.; Pan, S.; Hsieh, M.H.; Ng, N.; Sun, F.; Wang, T.; Kasibhatla, S.; Schuller, A.G.; Li, A.G.; Cheng, D.; et al. Targeting Wnt-driven cancer through the inhibition of Porcupine by LGK974. Proc. Natl. Acad. Sci. USA 2013, 110, 20224-20229. [CrossRef] [PubMed]

101. Rodriguez-Blanco, J.; Pednekar, L.; Penas, C.; Li, B.; Martin, V.; Long, J.; Lee, E.; Weiss, W.A.; Rodriguez, C.; Mehrdad, N.; et al. Inhibition of WNT signaling attenuates self-renewal of SHH-subgroup medulloblastoma. Oncogene 2017. [CrossRef] [PubMed] 